\title{
A REMARKABLE MURDER TRIAL: REX $\nabla$. SINNISIAK
}

\author{
By EDWIN R. KEEDY $\dagger$
}

In August, 1917, the writer attended the trial of Sinnisiak, an Eskimo, at Edmonton, in the Province of Alberta, Canada. Sinnisiak was charged ${ }^{1}$ with the murder of Rev. Father Rouvière, a priest of the order, Oblates of Mary Immaculate, ${ }^{2}$ at Bloody Falls on the Coppermine River near Coronation Gulf on the Arctic Ocean in November, 1913. It was the writer's plan, at the time, to publish an account of the trial, and for this purpose secured a copy of the Report of the Royal Northwest Mounted Police regarding the investigation of the case, and also a transcript of the proceedings at the trial. A delay of thirty-four years has occurred in carrying out the plan for publication, but it is believed that the interesting and unusual features of this trial warrant a presentation even at this late date. ${ }^{3}$ The provisions of the Canadian Criminal Code which governed the investigation and trial are set forth in the footnotes.

During the summer of 1913 the Rev. Fathers Rouvière and Le Roux, ${ }^{4}$ both members of the Oblate Order, left Fort Norman on the McKenzie River for the northeast shores of Great Bear Lake for mis-

†A. B., 1899, Franklin and Marshall College; LL. B., 1906, Harvard University; LL.D., 1926, Franklin and Marshall College, 1950, University of Pennsylvania; Professor of Law Emeritus, University of Pennsylvania; Dean, University of Pennsylvania Law School 1940-1945; author of The Decline of Traditionalism and Individualism, 65 U. OF PA. L. Rxv. 764 (1917); The Third Degree and Legal Interrogation of Suspects, 85 U. OF PA. L. REV. 761 (1937); A Petition of Right: Archer-Shee v. the King, 87 U. OF PA. L. Rev. 895 (1939); The Prelininary Ir. vestigation of Crime in France, 88 U. of PA. L. REv. 385, 692, 915 (1940); History of the Pennsylvania Statute Creating Degrees of Murder, 97 U. OF PA. L. Rev. 759 (1949) ; George Sharswood-Professor of Law, 98 U. oF PA. L. REv. 685 (1950); A Problem of First Degree Murder: Fisher v. United States, 99 U. oF PA. L. REV. 267 (1950); and articles in other legal periodicals.

1. "In the provinces of Saskatchewan and Alberta, it shall not be necessary to prefer any bill of indictment before a grand jury, but it shall be sufficient that the trial of any person charged with a criminal offence be commenced by a formal charge in writing setting forth as in an indictment the offence with which he is charged." CAN. CrTM. CODE \$873a (1915).

2. This is a French order, Les Pères Oblats de Marie-Immaculée, the members being missionaries, who are "commanded to evangelize the poor." BuLIARD, INUK 10 (1951).

3. References to this trial and to the preceding investigation have appeared in a number of publications. See Stefansson, THE FrIENDLY ARCTIC 432 (1921); FINNIE, THE LURE OF THE NORTY 210 (1940) ; BulIARD, op. cit. supra note 2, at 16. It is believed, however, that no detailed account of the proceedings at the trial has previously been published.

4. The Eskimo name for priests is Akortoyoaluk-Long Robes. BuLIARd, op. cit. supra note 2 , at 77 . 
sionary work among the Eskimos. They expected to be absent for about two years. Nothing was ever heard from them but in the spring of 1915 rumors reached the authorities at Fort Norman that the priests had been killed by Eskimos. Inspector La Nauze and two constables of the Royal Northwest Mounted Police ${ }^{5}$ were sent with supplies to investigate the rumors and clear up the mystery of the missing priests. The officers, accompanied by an interpreter, reached Great Bear Lake in the fall of 1915 and encamped there for the winter. ${ }^{6}$ In the spring of 1916 Inspector La Nauze with his party proceeded to the shore of Coronation Gulf near the mouth of the Coppermine River, where he learned that the priests had been killed by Sinnisiak and Uluksak. Inspector La Nauze was shortly afterwards joined by Corporal Bruce of the Mounted Police who with several guides had set out from Hershel Island in the Arctic Ocean to make an independent search for the missing priests and had obtained from the Eskimos the vestments and breviaries of the priests and articles for the Mass used by them. ${ }^{8}$

Inspector La Nauze, who held a commission as a justice of the peace, ${ }^{9}$ on the complaint of Corporal Brice, ${ }^{10}$ issued a warrant for the arrest of Sinnisiak who was located in a deerskin tent, engaged in making a wooden bow, and was arrested on the warrant. ${ }^{11}$ In his report

5. In 1919 the Royal Northwest Mounted Police was designated the Royal Canadian Mounted Police. Can. Pub. Gen. Acts c. 28, §1 (1919 2d Sess.).

6. Report of Supt. A. E. C. McDonell at Peace River, Alberta, in REPORT of Royal Nortawest Mounted Police 139 (1916), hereafter cited as Police Report.

7. Report of Inspector La Nauze (May 23, 1916), PoLICE REPORT 197 (1916).

8. Report of Inspector Ia Nauze (June 7, 1916), Police Report 198 (1916).

9. "The superintendents, and such other officers [of the Royal Northwest Mounted Police] as the Governor in Council approves, shall be ex officio justices of the peace." Can. Rev. Stat. c. 91, § 12.2 (1906).

10. "Any one who, upon reasonable or probable grounds, believes that any person has committed an indictable offence may make a complaint or lay an information in writing and under oath before any magistrate or justice having jurisdiction to issue a warrant or summons against such accused person in respect of such offence."

CAN. CrIM. Code § 654 (1915).

11. "Warrant to Apprehend. "Canada,

"Northwest Territories.

"To all or any of the Peace Officers in the said Territories:

'Whereas Sinnisiak, 'Copper' Eskimo of Coronation gulf, N.W.T., has this day been charged upon oath before the undersigned, C. D. La Nauze, inspector, Royal N.W.M. Police, a justice of the peace in and for the said territories, for that he about November, A. D. 1913, at or near the Coppermine river, in the Northwest Territories, did wilfully murder one, the Rev. Father Le Roux, by stabbing him with a knife.

"These are therefore to command you, in His Majesty's name, forthwith to apprehend the said Sinnisiak, and to bring him before me (or some other justice of the peace in and for the said territories) to answer unto the said charge, and to be further dealt with according to law.

"Given under my hand and seal this seventh day of May, A.D. 1916, at Bernard Harbour, in the Territories aforesaid. 
the Inspector stated that "he appeared to be stunned with fear and I learned afterwards that he expected to be stabbed right then." 12 The interpreter, who accompanied the Inspector stated that Sinnisiak said, "If the white men kill me I will make medicine and the ship will go down in the ice and all will be drowned." 13 Following the arrest of Sinnisiak the Inspector, in his capacity as a justice of the peace, conducted a preliminary examination, at which Sinnisiak, after being warned that he need not make any statement, ${ }^{14}$ freely admitted that the priests were killed by him and Uluksak. He was accordingly committed for trial. ${ }^{15}$ Several days later Uluksak was arrested and, after a preliminary examination at which he admitted taking part in the killing, was committed for trial. ${ }^{16}$

Inspector La Nauze in his report stated the following:

"I have not deceived the murderers in any way, I have had it carefully explained to them that it is not for me to judge them but that the Big White Chief must decide what he will do with them. But it is hard for them to grasp the meaning of this, in their life they have no chief, everyone is equal, and their word 'Ishumatak' for chief literally translated means 'the thinker', the man who does the deciding or thinking for the party. As regards their religion they have none. . . .

"In conclusion, I might mention we were dealing with a still practically primitive people, a people who six years ago were discovered living in what might be termed a stone age, and hidden away in the vast sub-arctic spaces of the Northland of Canada." 17

It required more than a year for the officers to bring Sinnisiak and Uluksak from the Coppermine River to Edmonton. They also brought two interpreters and an elderly Eskimo, Koeha, who was to be a witness at the trial.

12. Report of Inspector La Nauze (June 7, 1916), PoLICE RePort 201 (1916).

13. Ibid.

14. At the conclusion of the evidence at a preliminary inquiry the justice shall address the accused as follows:

"Having heard the evidence, do you wish to say anything in answer to the charge? You are not bound to say anything, but whatever you do say will be taken down in writing and may be given in evidence against you at your trial. You must clearly understand that you have nothing to hope from any promise of favor and nothing to fear from any threat that may have been held out to you to induce you to make any admission or confession of guilt, but whatever you now say may be given in evidence against you upon your trial notwithstanding such promise or threat." Can. CrIM. CODE $\$ 684(2)$ (1915).

The interpreter had great difficulty in conveying to Sinnisiak the meaning of this warning. Transcript, 122 .

15. Police Report 221 (1916).

16. Id. at 225 (1916).

17. Report of Insector La Nauze (June 7, 1916) Police Report 204 (1916). 
II

Although the crime charged against the defendants was committed in the region of the Arctic Ocean more than two thousand miles from Edmonton, the trial in that city was authorized by a statute providing that an offense committed in any part of Canada not in a province duly constituted may be tried in any province as may be most convenient. ${ }^{18}$

The Chief Justice of the Supreme Court of Alberta ${ }^{19}$ presided at the trial, and the Canadian Minister of Justice ${ }^{20}$ appointed able and experienced counsel to represent the Crown ${ }^{21}$ and to conduct the defense. ${ }^{22}$ Although both the Eskimos had been charged with the murder of the two priests Crown counsel elected to proceed against Sinnisiak alone for the murder of Father Rouvière.

At the start of the trial the courtroom presented a dramatic spectacle. On the bench was the Chief Justice wearing a black silk gown, a similar gown being worn by each of the counsel. Appearing as witnesses for the Crown were the members of the Northwest Mounted Police, who had investigated the crime and brought the defendants from the Arctic Ocean, the Inspector in a uniform consisting of a dark blue tunic and light blue breeches, while the Corporal and the Constable wore breeches of the same color with scarlet tunics. Also appearing as witnesses for the Crown were several priests of the Oblate Order, each wearing a long black cassock with a large silver crucifix hanging by a chain from the neck. Displayed as exhibits were the vestments of Fathers Rouvière and Le Roux with the articles for the Mass used by them. In order that the jury, ${ }^{23}$ which was composed of prominent citizens, might observe the defendants as they appeared in their native habitat, they were dressed, at the opening of the trial, in the garments which they wore when taken into custody, consisting of a loose smock and hood of sealskin with loose trousers and soft boots of the same material. As the summer temperature at Edmonton was much too warm for such apparel each of the defendants was provided with a

18. Can. Criar. Code $\$ 586$ (1915).

19. Chief Justice Harvey.

20. The powers of the Minister of Justice are set forth in Can. Rev. Stat. c. 21, $\S 4(1906)$.

21. C.C. McCaul, K.C. and James Short, K.C.

22. J. E. Walbridge, K.C.

23. The practice of questioning jurors by counsel (voir dire examination) which is common in this country does not occur in Canada. In Rex v. Harri, 38 Can. Cr. Cas. 234 (1922) counsel for the prisoner desired to question a juror before he was sworn. The court ruled that this was not permissible.

The Code provides that in all cases, in which the accused may upon conviction be sentenced to death, the court shall order that the jurors be kept together and prevented from holding communication with any one on the subject of the trial. CAN. CRTMr. CODE $\$ 945$ (1915). 
wash tub, filled with water and blocks of ice, into which he placed his feet. After the first session of the trial the defendants wore suits of blue denim.

In his opening address to the jury Crown counsel stated that "The long arm of British Justice has reached out to the shore of the Arctic Ocean, and has made prisoners of two of the aboriginal inhabitants of the Arctic Shore, suspected of committing the crime in question." 24 He also stated that "the great importance of the trial consists in this: that for the first time in history these people, these Arctic people, prehistoric people, people who are as nearly as possible living today in the Stone Age, will be brought in contact with and will be taught what is the white-man's justice." 25

The first witness was Father Duchasoir, of the Oblate Order, who identified the vestments of Father Rouvière and the articles for the Mass used by him, also letters received from him by his superiors at Fort Norman.

The second witness was Corporal Bruce who described his search for the priests and his discovery of their vestments and articles for the Mass.

On cross-examination he was questioned as follows regarding the Eskimos of the Coppermine River, generally known as the Copper Eskimos:

Q. "What manner of people did you find them?

A. "Very simple, kindly as a rule.

Q. "What about their intelligence?

A. "Well, they are very clever in their work, but their minds don't work like ours.

Q. "They compare more with children, don't they, than with grown up people as far as we are concerned?

A. "As regards our ways, it is a hard question to answer.

Q. "That is what I say, as regards our ways, our methods of doing things, they are simple like children?

A. "Yes; they want to examine everything; they are very curious to find out about things, how it is made and how it is done.

Q. "What you would call primitive?

A. "Yes, they are primitive."26

The witness was also questioned regarding the religion of the Copper Eskimos. The following questions and answers are significant:

24. Pamphlet, Opening Address of Counsel for the Prosecution 4.

25. Id. at 7. Counsel also stated the following: "These remote savages, really cannibals, the Eskimo of the Arctic regions have got to be taught to recognize the authority of the British Crown, and that the authority of the Crown and of the Dominion of Canada, of which these countries are a part, extends to the furthermost limits of the frozen North." Id. at 6.

26. Transcript, 61 . 
Q. "Do you know anything about these people's religion?

A. "Yes, that is, according to ethnologists, their religion consists of a series of taboos. ${ }^{27}$

Q. "Good spirits and evil spirits?

A. "Yes.

Q. "Things they should do and things they should not do?

A. "Yes.

Q. "I understand they think these spirits come to them in human form?

.A. "Yes. Those are imaginary spirits they call down. They sometimes say they see spirits, performing that way." 28

When asked to name some of the "taboos," the witness stated "they are not supposed to eat caribou meat on the ice" and "women are not supposed to sew in the full of the moon." 29

When asked about the custom after a caribou was killed the witness said "they generally cut a little piece off of it and throw it to one side." Then followed these questions and answers:

Q. "Do you know the reason of that? Did you ever hear of that because the caribou has spirits?

'A. "I understood it to be that.

Q. "Spirits go along with the caribou, and they have to appease those spirits?

A. "Yes"."30

When asked whether the Eskimos practiced any form of punishment the witness replied, "Not that I know of except they have blood feuds there." 31

On cross-examination regarding his approach to the village where Sinnisiak was arrested the witness testified that he did not carry a gun because he didn't want to cause any fear among the Eskimos. ${ }^{32}$

After testimony by the Constable who accompanied Inspector $\mathrm{La}$ Nauze, confirming the testimony of Corporal Bruce regarding the arrest of Sinnisiak, Koeha, the elderly Eskimo, who was brought to Edmonton with the defendants, was called as a witness. After being sworn by the formula "Whatever you speak now you speak straight,

27. See Stefansson, My LIFe WITH the Eskrmos 411-413 (1913). Regarding taboos among primitive peoples see particularly FRAzER, THE GoLDEN BOUGH 194-262 (1926). See also Seligman, The Melanesians of British New Guinea 130, 563 (1910); TALBOT, LIFE IN SoutherN NIGERIA 220-232 (1923); RoscoE, The Bagesu 110-121 (1924).

28. Transcript, 66 .

29. Id. at 67 .

30. Id. at 68 .

31. $I d$. at 70 .

32. $I d$, at 101. 
don't speak with two tongues," ${ }^{33}$ the witness testified through an interpreter. He first stated that the priests were given Eskimo names, Kuleavik for Father Rouvière and Ilogoak for Father Le Roux. He

33. Id. at 108. The oath to a witness is ordinarily administered as follows:

"In administering the oath the witness should hold the New Testament, or Bible, in his right hand, which should be bare and ungloved. And the witness shall be addressed as follows: "The evidence that you will give to the court touching the matters in question shall be the truth, the whole truth, and nothing but the truth, so help you God." Daly, Canadian Criminal Procedure and Practice 126 (3d ed. 1936).

Interesting questions regarding the swearing of non-Christian witnesses arose in several other Canadian cases.

In King v. Lai Ping, 8 Can. Cr. Cas. 467 (1904), the prisoner, who was not a Christian, before being sworn was asked how he swore, and intimated to the Magistrate that he swore through burning paper, and he then wrote his name on a piece of paper and burned the paper, and was told "that he was to tell the truth, the whole truth and nothing but the truth or his soul would burn up as the paper had been burned." This method of swearing was held to be valid.

The case of King v. Ah Wooey, 8 Can. Cr. Cas. 25 (1902), is particularly interesting. The report is as follows:

"A Chinaman was upon trial charged with murder. On a Chinese witness, Chong Fon Fi, not a Christian, being called for the Crown, it was proposed to swear him through the interpreter in the manner generally adopted in the Courts of this Province, i. e., by writing his name on a piece of paper and burning it, at the same time declaring that he would tell the truth: the consumption of the paper by fire signifying the fate of his soul if he should fail to do so.

"Wilson, K.C., (Bloomfield, with him), for the prisoner. I object to this form of oath and am instructed that there is another form of greater solemnity and which will be more binding on the witness' conscience: it is commonly called in this Province the 'chicken oath,' and I ask in a case of this gravity that it be administered.

"Martin, J., interrogated the local interpreter, Charlie Loo Fook, and also the official interpreter from Victoria, Yip. Wing, who was present in Court assisting the Crown, and instructed them to examine the witness on the point, which being done, they informed the Court that the oath which is known to the Chinese in British Columbia (almost all of whom come from the Province of Canton) as the 'King's oath,' is the oath to the King of heaven, or, as the white people call it, the 'chicken oath,' was the more binding. oath.'

"The learned judge thereupon directed that the witness be sworn by the 'King's

"A discussion arising on the form of said oath, it was finally settled by the interpreters, and written on yellow Chinese paper as follows:

\section{(Translation.)}

" 'King's oath' made by . . . (Witness signs his name here)

(Recites charge against accused, and proceeds.)

"Being a true witness, I shall enjoy happiness and $m y$ sons and grandsons will prosper forever.

"If I falsely accuse (prisoner) I shall die on the street, Heaven will punish me, earth will destroy me, I shall forever suffer adversity, and all my offspring be exterminated. In burning this oath I humbly submit myself to the will of Heaven which has brilliant eyes to see.

"The 27th year of the reign

of $\mathrm{K}$ wang $\mathrm{Su}$, the 16th day,

the 9 th Moon.

(Witness also signs here.)

"The witness having signed his name twice, and a cock having been procured, the Court and jury adjourned to a convenient place outside the building where the full ceremony of administering the oath was performed, as follows: By a block of wood, punk sticks, not less than three, and a pair of Chinese candles were stuck in the ground and lighted. The oath was then read out loud by the witness, after which he wrapped it in Joss-paper as used in religious ceremonies, then laid the 
also identified photographs of the priests. He was then questioned by Crown counsel regarding his knowledge of the killing of the priests. This involved the asking of many leading questions, some of which were objected to by counsel for the defense. The judge, however, allowed Crown counsel considerable latitude in this respect. Much difficulty was experienced with the interpreter, who did not always understand the questions put to the witness. In some instances these were translated to the interpreter in "pigeon English" by one of the Mounted Police. The extent of the difficulty with the interpreter is indicated by the following dialogue:

MR. WALLBRIDGE: "My lord, the interpreter Patsy informs me that this interpreter is putting him [the witness] through the third degree, is accusing him of lying, and trying to get him to give an answer which the Eskimo doesn't want to give.

THE CourT: "Ilavinik, just ask him the question that counsel give you. Do not say any more to him. Just get him to answer that. You can explain that to him, but do not ask him anything else, and do not say anything else to him." 34

At this point in the trial Crown counsel offered in evidence the statement made by Sinnisiak at the preliminary hearing. ${ }^{35}$ The Court

cock on the block and chopped its head off, and then set fire to the oath from the candles and held it until it was consumed."

In Regina v. Pah-Mah-Gay, 20 U.C.Q.B. 195 (1860) the witness, an Indian of the Pottawattomie nation, was sworn in the common way on the Gospels.

"After he was sworn, the learned Chief Justice found, by questions put to him through an interpreter, that he had full sense of the obligation to speak truth, but that he was not a Christian, and had no knowledge of any religious or other ceremony or form binding a person to speak the truth, or of any form of asseveration or of appeal to a Superior Power to attest his veracity, or of imprecating punishment upon himself if he should assert what was false. He and his tribe believed in a future state, and in a Supreme Being, who created all things; and in a future state, where the measure of success in hunting and of happiness would depend upon their conduct in this life." Id. at 196.

In holding the oath valid the Court stated the following:

"He believed in a Supreme Being, who created all things, and in a future state of rewards or punishments, a life after this in which those who have died here will be more or less happy, according to their conduct on earth.

"He evinced a strong sense of the obligation to speak truth, and in taking the oath, which was explained to him, he invoked in the usual terms the Supreme Being so to aid him as he should speak the truth. . . .

"The oath upon the Gospels had no signification in his case. He is not a Christian, and has no belief in them; but he believed in a Good Spirit or Supreme Being, and in a future state of rewards or punishments. It is by no means necessary that his idea of a Great Spirit should agree with a Christian's knowledge of God. His holding the Testament in his hand, or kissing it, did at least no harm, and when, after invoking God or the Supreme Being, he made his statement, he did all that a Gentoo, or Turk, or Chinese, could do, except the going through some ceremony, which he could not do, because none was known in his tribe that was connected with the position of a witness, or supplied any additional obligation upon him to adhere to truth." Id. at 198.

34. Transcript, 114.

35. $I d$. at 117. 
of its own motion directed that the interpreter, Ilavinik, who was the interpreter at the preliminary hearing, be questioned as to whether he interpreted correctly. ${ }^{36}$ Ilavinik was accordingly sworn as a witness and testified that Sinnisiak's statement was the result of questions put to him, the answers being correctly interpreted. He stated that he put questions to Sinnisiak "pretty nearly all day." ${ }^{37}$ The statement of Sinnisiak, which was then admitted in evidence, ${ }^{38}$ was as follows:

"The accused being duly warned in the usual manner makes the following statement:

"I was stopping at the mouth of the Coppermine River and was going fishing one morning. A lot of people were going fishing. When the sun had not gone down I returned to camp and saw that the two Priests had started back up the river. They had four dogs. I saw no other men.

"I slept one night. Next morning I started with one dog. I help people coming from the south. All day I walked along and then I left the river and travelled on the land, I was following the priests' trail. I met the priests near a lake, when I was close to them one man came to meet me. The man Ilogoak, the big man came to me and told me to come over to the camp. Ilogoak said to me 'if you help me pull the sled I will pay you in traps.' We moved off the same day I arrived to be near wood, Uluksak was with me and we pulled the sled. We could not make the trees, it was hard work and we made camp.

"The next day we started back and the priests were going ahead, it started to storm and we lost the road. After that the dogs smelt something and Uluksak went to see what it was and I stayed behind. Uluksak found it was a cache of the priests and told me to come over. As soon as we got there the priests came back.

"Tlogoak was carrying a rifle, he was mad with us when we started back from their camp and I could not understand his talk. I asked Ilogoak if he was going to kill me and he nodded his head. Ilogoak said 'come over to the sled' and pushed me with his hand.

"The priests wanted to start again and he pushed me again and wanted me to put on the harness and then he took his rifle out on top of the sled. I was scared and I started to pull.

36. Id. at 118 .

37. $I d$. at 124 .

38. Id. at 132. "The statement made by the accused before the justice may, if necessary, upon the trial of such person, be given in evidence against him without further proof thereof, unless it is proved that the justice purporting to have signed the same did not in fact sign the same." CAN. CRIM. CODE $\$ 1001$ (1915).

Where a statement made by the accused upon a preliminary inquiry and then reduced to writing and signed by the accused was shown to have been taken through an interpreter it is nevertheless admissible in evidence at the trial and the onus is not cast upon the Crown to prove that the interpreter correctly interpreted the statutory warning to the accused and the statement made by the accused. King v. Walebek, 21 Can. Cr. Cas. 130 (1913). 
"We went a little way and Uluksak and I started to talk and Ilogoak put his hand on my mouth.

"Ilogoak was very mad, and was pushing me. I was thinking hard and crying and very scared and the frost was in my boots and I was cold.

"I wanted to go back, I was afraid. Ilogoak would not let us. Every time the sled stuck Ilogoak would pull out the rifle.

"I got hot inside my body and every time Ilogoak pulled out the rifle I was very much afraid.

"I said to Uluksak, I think they will kill us, I can't get back now. I was thinking I will not see my people any more I will try and kill him. I was pulling ahead of the dogs. We came to a small hill. I took off the harness quick and ran to one side and Ilogoak ran after me and he pushed me back to the sled. I took off my belt and told Ilogoak I was going to 'relieve myself' as I did not want to go to the sled. After that I ran behind the sled, I did not want to relieve myself. Then Ilogoak turned around and saw me, he looked away from me and I stabbed him in the back with a knife. I then told Uluksak 'you take the rifle.' Ilogoak ran ahead of the sled and Uluksak went after him. The other white man wanted to come back to the sled. I had the knife in my hand and he went away again. Uluksak and Ilogoak were wrestling for the rifle and after that Uluksak finished up Ilogoak. I did not see Uluksak finish him. The other man ran away when he saw Ilogoak die. I asked Uluksak is he dead, and he said yes already. I then said to Uluksak 'give me the rifle.' $\mathrm{He}$ gave it to me. The first time I shot I did not hit him the second time I got him. The priest sat down when the bullet struck him. I went after him with the knife, when I was close to him he got up again, both of us were together. I had the knife in my hand and I went after him when he got up again.

'Uluksak told me 'go ahead and put the knife in him.' The priest fell down on his back. I said to Uluksak 'go ahead you I fixed the other man already.' Uluksak struck first with the knife and did not strike him the second time he got him. The priest lay down and was breathing a little. I struck him with an axe I was carrying across the face. I cut his legs with the axe. I killed him dead.

"One man is in a creek, the first one along side the sled.

"After they were dead I said to Uluksak before when white men were killed they used to cut off some and eat some. Uluksak cut up Ilogoak's belly. I turned around.

"Uluksak gave me a little piece of the liver. I eat it. Uluksak eat too.

"We covered up both bodies with snow when we started to go back. We each took a rifle and cartridges. We took 3 bags of 
cartridges each. We started back in the night time. We camped that night.

"Next morning we got back to camp as soon as it was light.

"I went into Kormik's tent. Kormik was sleeping and I woke him up. I told him I kill those two fellows already. I can't remember what Kormik said. Kormik, Koeha, Angibrunna, Kallun, Kingordlik went to get the priests stuff. They started in the morning and came back the same night. Kormik had two church shirts and some clothing. I can't remember the other things. Kormik sold the two church shirts to A. Nautallik. I do not know what he got for them. I can't tell any more. If I knew more I would tell you, I can't remember any more.

"Witness and Interpreter:

"Interpreter. X Ilavinik (Sgd)

"Witness (Sgd) W. V. Bruce, Cpl.

"C. D. La Nauze,

J. P." 39

The next witness was Inspector La Nauze, who described his search for the priests and told of his meeting with Corporal Bruce at the mouth of the Coppermine River in the spring of 1916. He stated that he obtained an interpreter, Ilavinik, ${ }^{40}$ who had been with Stefansson when he made his trip to this region. He then described the arrest of Sinnisiak. He stated that he entered a tent where he was informed he would find Sinnisiak. He then said: "The first thing I saw was a man sitting at the far end of the tent. He was engaged in the manufacture of a bow, and he sat there trembling, in fact he was shaking all over." 41

Regarding the attitude of the Eskimos, who were present when Sinnisiak was arrested, the witness testified as follows: "I simply explained our mission, and rather curious to relate, the people were all on our side. They turned around and said, 'You must do what the white man tells you; you have got to go with them,' and after that we got quietly away from the camp." 42

On cross-examination of the witness the following dialogue occurred:

Q. "And the story you got from all of them, as well as the story you got from this prisoner, the information you got was that these men had killed the priests out of fear?
A. "Out of fear?
Q. "Yes.

39. Transcript, $133-136$.

40. Id. at" 142 .

41. Id. at 145 .

42. Id. at 147 . 
defence?

A. "No, I don't know.

Q. "Your report says that they had killed them in self-

A. "I said they might have, I think." 43

Questioned regarding the arrest of Sinnisiak he stated that Sinnisiak undoubtedly thought that he was going to be killed "on the spot." 44

Counsel for the defense then read to the witness the following statement from Stefannson's book, $M y$ Life among the Eskimos: "Like our distant ancestors, no doubt, these people fear most of all things the evil spirits that are likely to appear to them at any time in any guise, and next to that they fear strangers." The witness was then asked whether this was "a fair statement," to which he replied, "Well, Stefannson is an authority". 45

The attention of the witness was called to the following statement of his report: "Their own defence of being ill-treated is their strongest point, and the prosecution has no witness that will deny this." He was then asked: "You were unable to find any?" To which he replied "No." 48 The witness also confirmed that his report contained the following statement: "The unfortunate priests may have been the victims of a premeditated murder for the possession of their rifles and ammunition, or may have brought on the crime by their own untactfulness." He was then asked: "I want to know whether you had any information that would suggest this untactfulness"? To this he replied: "Yes, I thought so possibly by the prisoner's statements." 47

The witness was asked: "And if a white man, a stranger, holds a gun on an Eskimo, the Eskimo hasn't any other notion but what it is going to be used? There is no doubt?" The answer was "No doubt." 48

Koeha, being recalled as a witness, testified regarding the priests' relations with the Eskimos. He was asked: "Had the priests been pretty good to the Eskimo, to the Huskies?" To this he replied: "Yes, they had been good." He also stated that the priests had taught the

43. Id. at 152 .

44. Id. at 153 .

45. Id. at 159 .

46. $I d$. at 160 .

47. Id. at 163. StzFansson, writing in 1921, stated that "the' only practicable method of treating Eskimos who meet a white man for the first time is to deal with them as equals." He then expressed the opinion that failure to do this was the reason why Fathers Rouvière and Le Roux were killed. THe FrIendLy ArCTIC 432 (1921).

48. Transcript, 161. 
Eskimos to catch fish with nets. ${ }^{49}$ Following is a portion of the crossexamination:

Q. "Did you know the first time you saw Ilogoak that he was a priest, a missionary? Do you know what a priest is?

A. "No.

Q. "Did you know that Kuleavik was a priest?

A. "I didn't know.

Q. "Did you think they were trappers or traders?

A. "I think they come down for caribou, think they were hunters and traders."

During the cross-examination the witness was questioned about spirits as follows:

Q. "Do you like to talk about spirits?

The Interpreter: "He doesn't want to speak.

Q. "Are you afraid to speak about spirits?

A. "I am not afraid. spirits?

Q. (to interpreter) "But he doesn't like to speak about

The Interpreter: "No.

Q. "Is it unlucky to speak about spirits?

A. "Yes." 51

At the completion of the testimony of Koeha the Crown rested.

Sinnisiak, the defendant, was then called as a witness and sworn by the interpreter. ${ }^{52}$ Counsel for the defense then directed the interpreter to make the following statement to the defendant:

"Tell him, first, I want him to speak to the big chief, and I want him not to be afraid, and to say everything. You tell him that. Tell him not to be afraid because all these people are here, to just talk to me as if he was talking to me alone."

On direct examination the testimony of the defendant was substantially the same as his statement made at the preliminary hearing, which had previously been put in evidence by Crown counsel. ${ }^{54} \mathrm{He}$ testified specifically that "When we started off-every time we tried to

49. Id. at 170. A Canadian explorer, writing in 1914, stated that his observations regarding the work of the Oblate Fathers among the Eskimos gave him "an unbounded respect for these devoted self-sacrificing men." DOUGLAS, LANDS FORLORN 231 (1914).

50. Id. at 181 .

51. Id. at 186 .

52. The oath administered to the witness was: "Whatever you speak now, you speak straight; don't speak with two tongues." Id. at 196.

53. Ibid.

54. See note 38 supra. 
get out of the harness the priest had his gun and was going to shoot me." ${ }^{55}$ He testified further that he thought he was going to be killed. ${ }^{56}$

Regarding spirits the defendant testified as follows:

Q. "Why did you eat a piece of the dead man's liver?

A. "Because I heard from my grandfather-I heard about it from my grandfather.

Q. "Did you know what it was going to do for you to eat the liver?

A. "The man might get up again if I didn't eat his liver."

Q. "Do you like to talk about spirits?

A. "I don't know. spirits?

Q. "You don't know what? Do you like to talk about

A. "I don't know how to speak about spirits.

Q. "Do you know about spirits? Do you know anything about spirits?

A. "I know about spirits.

Q. "Has the eating of the liver anything to do with spirits?

A. "I think maybe the spirits make the man alive." 58

The defendant testified that before the arrival of the priests he had seen three white men-Stefansson and two prospectors.

At the conclusion of the defendant's testimony Crown counsel stated that he would not cross-examine him, but would "go to the jury on the evidence in the shape in which it is." 59

55. Transcript, 202.

56. Id. at 207.

57. Professor Morris Jastrow, Jr., of the University of Pennsylvania stated that references to the liver as the seat of the soul (spirit) are found in the literature of the Babylonians, Assyrians, Hebrews, Chinese, Etruscans, Greeks and Romans. Jastrow, The Liver as the Seat of the Soul, STUDIES IN THE HISTORY OF REITGIONS 143 (1912). He refers to the passage in the Iliad where Hecuba, the mother of Hector, vowing vengeance for his death "declares that she will not rest until she has devoured the "liver' of Achilles." Id. at 148. Iliad, XXIV, 212.

It has also been pointed out that among some of the primitive peoples in Africa the liver is believed to be the seat of the spirit. CRAWLEY, THE IDEA OF THE SOUL 93, 110, 131 (1909).

Dr. William Curtis Farabee, a member of the staff of the University of Pennsylvania Museum, who during the years 1913-1916 conducted explorations in northwestern Brazil, informed the writer that the natives of that region believed the liver was the seat of the spirit.

58. Transcript, 217. A "kind of magical cannibalism consists in the consumption of a small portion of the body of a murdered man, in order that his ghost may not trouble the murderer." 4 ENCY. BRTT. 746 (14th ed. 1929).

"It is quite usual for savage tribes to live in terror of the souls of the dead as harmful spirits." 2 Tylor, Primittve Culture 111 (1913).

"Among the modern Arabs the soul of a murdered man must be nailed down." Thompson, Semitic Magic 17 (1908).

59. Transcript, 219. 
Counsel for the defendant now addressed the Court and jury. $\mathrm{He}$ contended that the defendant should be judged by the standard of his own people and not by the standard of civilized persons. He argued for an acquittal on two grounds (1) that the defendant should be treated as a young child and should be judged by the standard of his own people and (2) that he acted in self defense, reasonably believing that he was in danger of being killed by the priests.

In his closing address to the Court and jury Crown counsel stated by way of introduction the following:

"The object of giving these people the advantage of British justice and British fair play is to make it known that if the white men, travelling in that country, are killed, that the tribe will not be exterminated, that no punitive expedition will exterminate them, but that they will be given the same fair trial as any white man, Englishman or Canadian, would get under similar circumstances." 60

Crown counsel contended that the evidence showed the defendant and Uluksak planned to murder the priests for their rifles. With regard to the argument of counsel for the defense that the defendant should not be judged by the ordinary standard of civilized persons Crown counsel replied that this argument did not apply to the question of guilt but to mitigation of punishment, and should be addressed not to the judge and jury but to the Governor in Council after conviction. ${ }^{61}$

The Court commenced ${ }^{62}$ his charge to the jury ${ }^{83}$ by stating the following :

60. Id. at 222.

61. Id. at 223 .

62. The introductory paragraph of the judge's charge was as follows:

"Gentlemen of the Jury-The crime of which the prisoner is accused is the most serious that is known to our law, and naturally that will impress upon you the solemnity of your duty, because it is on you, and on you only, that the duty is cast of determining whether or not he is guilty or not guilty of the charge." Transcript, 234.

This is reminiscent of the opening of the address to the jury by counsel for the defense in the famous trial of Madeleine Smith, which was as follows:

"Gentlemen of the jury, the charge against the prisoner is murder, and the punishment of murder is death; and that simple statement is sufficient to suggest to us the awful solemnity of the occasion which brings you and me face to face." Trial of Madeleine SMith 211 (Notable Scottish Trials, 1905).

63. "The Judge realizing the importance of the trial as affecting the safety of the public and the liberty of the accused, approached his task with a full realization of the consequences of the jury's verdict. With great care and accuracy he defined and explained the law applicable to the case, and after doing this, reviewed with admirable thoroughness and ability the salient features of the evidence. In this review he was not required under our system of jurisprudence, to refer to every bit of the evidence adduced; his duty was to define the issues involved, making such references to the evidence as should enable the jury fairly to consider these issues." Macdonald, C.J.A. in Rex v. Boak, 44 Can. Cr. Cas. 225, 226 (1925).

"Now it is well said a Judge in his instructions to the jury should put the facts of both sides in such a way as to assist the jury in coming to their conclusion, not that his opinion should influence them but that his collection of the facts would assist them." Macdonald, C.J.B.C. in Rex v. McKenzie, 58 Can. Cr. Cas. 106, 115 (1932). 
"The fact that he is a poor, ignorant benighted pagan, who comes from beyond the borders of our civilization, does not stand in the way of his receiving all the protection that our law can give any person charged with any offence. As you have seen he has been furnished with counsel, not some junior counsel who might be desirous of getting the experience of defending an important case, but he has been provided as counsel with one of the leaders of the bar, who has left no stone unturned during the course of this trial to see that no unfair advantage was taken of the accused, and to see that everything that might be brought out in his favor should be brought out. Owing to the circumstances of this case, the particular circumstances, I instructed the sheriff, when empanelling the jury, to see that no perșon was put on the panel of jurors except men of the highest standing in the community. I thought it only fair that the prisoner should have the best that our country can afford in answering a charge such as this." 64

Regarding the contention that the defendant should be judged by the standard of his own people the Court charged as follows:

"Much has been suggested in the present case about the prisoner's lack of knowledge of our law and our customs, and his own custom. Of course, that applies to a greater or less extent to many of the foreigners who have come into our country; to the Indians, although they have to become gradually more and more accustomed to our laws, but that can not be dealt with by the court such as this is in considering the liability for the crime. In law a person must be considered liable. In fact, there is a very great difference. That is a matter to be dealt with in the matter of punishment." 65

The Court disposed of the claim of self defense as follows:

"The question then would seem largely to be one between culpable homicide and excusable or justifiable homicide. Now, homicide is justified if it is done in self defence, but self defence does not mean prevention. We have, of course, in the last two or three years had pressed upon us very frequently the question of self defence in a way that is more or less applicable to this. Germany has declared that she is making this war as a war of self defence. Assuming that she is honest, all of us consider it is not self defence as we look upon self defence. It may be for the purpose of preventing what she fears, but it is not defending herself against an attack because she attacked first. That perhaps is her view of self defence, and that is a view of self defence that has been advanced as an excuse for killing within our own memory. We have accounts of it in the early unsettled portions of the country where the law is not strictly enforced of people taking the law

64. Transcript, 234.

65. Id. at 235 . 
in their own hands. Where they feared, and had good reasons to fear, men might kill them, they kill the person to prevent it. That is not self defence. That is an attempt to prevent, but it is not under our law permissible. Now, the self defence, as it is known to our law, that is, the excuse for the killing, is the defence against attack, a defence against an assault of some sort." 66

In conclusion the Court charged as follows:

"It is your duty to deal with this case calmly and deliberately and not to be affected by your sympathies, but allow your judgment full sway. I say that is your duty. You are human, however, and you have your sympathies as you can not help having them, and they, no doubt, will have some effect upon you; and I want to say to you, therefore, that while it is your duty to find a verdict of murder, if you view the case largely as I have suggested it to you and on that verdict, if you find it, it will be my duty to pass the sentence of death; that would be the only sentence that I could pass. Yet I have no hesitation in saying to you that I would consider it a crime that this man should be executed for the act with which he has been, and for which he is being, charged here. It is there that his condition, his absence of knowledge, his customs, and his absence of knowledge of our customs should have effect, and I would be bound, in the exercise of my duty, to recommend that the sentence of death should not be carried out, and I have no doubt whatever that the authorities would recommend to His Excellency, the Governor General, that he should not be executed, but that some other form of punishment would be imposed which would meet the requirements of the case, and which would take home to him and to the members of his tribe the knowledge of our laws and our measure of justice. I have no doubt that some such punishment as that would be given to him, and not that the extreme penalty of the law would be exercised. I tell you that so that you may feel freer perhaps to do what the law demands of you, but which might perhaps be abhorrent to your sentiments of humanity if you felt that the strict letter of the law would have to be carried out." ${ }^{67}$

The jury retired to consider their verdict at 12:03 o'clock and at $1: 10$ P. M. returned the following verdict: "Not guilty." ${ }^{88}$

\section{III}

After the acquittal of Sinnisiak for the murder of Father Rouvière the authorities decided to try both Sinnisiak and Uluksak jointly for the murder of Father Le Roux. Acting under a statute which gives the court authority to change the venue Chief Justice Harvey directed that

66. Id. at 239 . charge.

67. Id. at 241. Counsel for the defendant took exception to this portion of the

68. Id. at 245 . 
the trial should occur in Calgary, about 200 miles south of Edmonton. ${ }^{69}$ The trial ${ }^{70}$ started six days after the close of the trial in Edmonton and lasted three days. The evidence for the prosecution was in substance the same as in the trial at Edmonton. Both Sinnisiak and Uluksak testified as witnesses for the defence. Sinnisiak's testimony was practically identical with that given by him in the Edmonton trial. When Uluksak took the stand he was asked how old he was. He replied: "Maybe I am eight years old (holding up fingers of both hands)." ${ }^{71}$ Uluksak's testimony was the same as his statement made at the preliminary hearing. The addresses of counsel and the charge of the Court were similar to those at Edmonton. There was an added statement by defense counsel regarding the independent nature of the Eskimos. He said: "There are natives who can be treated with the whip, natives of Africa I understand, thrashed into the way of the white man, made to do his bidding. But that is not the way with the Eskimo; he is a free, independent man. You can not coerce him. You can coax him; you can make him do your bidding by kindness, but you can not coerce him. His motto is the one made famous by Patrick Henry, 'Give me liberty or give me death." " 72 With regard to the eating of portions of the priest's liver Crown counsel stated the following: "That comes under the head of cannibalism as described in the Encyclopedia Britannica which says it may be divided according to the motives of the act, and he mentions a species of cannibalism called protective cannibalism 'which consists in the consumption of a small portion of the body of a murdered man, in order that his ghost may not trouble the murderer.' . . . That was the idea, that the ghost of these men would haunt them." 73

Following the Court's charge the jury, after deliberating for fortyfive minutes, returned the following verdict: "We find the prisoners guilty of murder, with the strongest possible recommendation to mercy that the Jury can give." 74 The Court then addressed the jury:

69. "Whenever it appears to the satisfaction of the court or judge herein mentioned, that it is expedient to the ends of justice that the trial of any person charged with an indictable offence should be held in some district, county, or place other than that in which the offence is supposed to have been committed, or would otherwise be triable, the court before which such person is or is liable to be indicted may, at any term or sitting thereof, and any judge who might hold or sit in such court may, at any other time, either before or after the presentation of a bill of indictment, order that the trial shall be proceeded with in some other district, county or place within the same province, named by the court or judge in such order." CAN. CRIM. CODE $\$ 884$ - (1915).

70. The writer did not attend this trial but procured a transcript of the proceedings.

71. Transcript, 50 .

72. Id. at 92 .

73. Id. at 105 .

74. Id. at 128. 
"Gentlemen of the jury: You have performed a very unpleasant duty and, I think, have come to exactly the correct conclusion in all respects. I think the verdict is the only honest verdict that could be rendered on the evidence and the recommendation is most proper. It will be submitted by me with my own recommendations to the same effect at once." 75

The Court then announced sentence would be deferred. He then directed the interpreter to tell the defendants to stand, whereupon he spoke the following: "Patsy, tell them that the jury have found that they were guilty of killing the priests without right to do it; that under our law when people kill others that way they have to give their lives, but the great white chief further away than the distance they have come may interfere and show them mercy, may be kind to them." 78

The Court then remanded the defendants to the custody of the police to be taken back to Edmonton and stated that he would telegraph at once to the Minister of Justice. ${ }^{77}$

Several days later in Edmonton the Chief Justice imposed sentence as follows:

"Patsy, tell the prisoners to stand up. Tell them what I have to say. You told them in Calgary the other day that I would ask the Big Chief far away not to be too hard on them, and I have asked him by the way we have here, a long way, by telegraph, and he says because they did not know our ways, that they did not know what our laws are, he will not have them put to death for the killing of these men this time. They must understand though that for the future they know now what our law is and if they kill any person again then they have to suffer the penalty.

"I am going to pass sentence. I do not think it is necessary to explain the particulars of it now, but in the usual course action will be taken so that it will not be carried out. I impose the sentence of death in the usual form, ${ }^{78}$ and I will fix the 15 th of October as the date of execution. That is, of course, under the circumstances, something more or less a matter of form, but it is a form the Minister desires to have the proceedings take so that the commutation of the sentence may be in the usual way. He authorizes me to state the sentence will be commuted. You may tell them just what will be done I cannot say, but they will know in a few days. They will probably be punished in some way, but I do not know just in what form it will be.

"Patsy, you might tell them when they get back home, if they do, they must let their people know that if any of them kill

75. Ibid.

76. Id. at 129.

77. Ibid.

78. "Every one who commits murder is guilty of an indictable offence and shall, on conviction thereof, be sentenced to death." CAN. CRIM. CODE $\$ 263$ (1915). 
any person they will have to suffer death. They know now what our law is."

The sentence of death was commuted, on August 19th, by the Governor in Council to life imprisonment at the Mounted Police guardroom at Herschel Island in the Arctic Ocean. ${ }^{79}$ The following day the place of detention was changed to Fort Resolution on Great Slave Lake in the Northwest Territories. ${ }^{80}$

On May 15, 1919, by order of the Governor in Council, Sinnisiak and Uluksak were released from custody and permitted to return to the region from which they were taken. ${ }^{81}$ The following conditions formed part of the order of release:

". . . it has been determined that they may be set at liberty conditionally upon their undertaking solemnly for the future to respect human life and property, and to make known to the members of their band and native associates, in addition to the facts aforesaid, that the Eskimos live and are governed under a system of law which, with equality as against both white man, Indian and Eskimo, exacts speedy and rigorous punishment for crime according to the degree, and that by mandate of the law, capital punishment must follow a capital offence; and moreover that while for the reasons aforesaid these prisoners have been visited by a dispensation of mercy whereby their lives have been spared, notwithstanding the offence which they committed, these reasons are not likely to be permitted to avail on another occasion, either for them or for any other Eskimo, seeing that the proceedings in the present case have served to inform them of their responsibilities, and that they are solemnly charged with their duty to serve God and honour the King and carefully to observe his laws". ${ }^{82}$

79. "The Crown may commute the sentence of death passed upon any person convicted of a capital offence to imprisonment in the penitentiary for life, or for any term of years, not less than two years, or to imprisonment in any gaol or other place of confinement for any period less than two years, with or without hard labor." CaN. CRIM. CODE $\S 1077$ (1915). 1951.

80. Letter to writer from the Canadian Minister of Justice, dated August 20 ,

81. Ibid.

82. Ibid. 